\title{
The Importance of Preventive Physiotherapy in Patients Diagnosed with Prostate Cancer
}

\section{Prostat Kanseri Tanılı Hastalarda Koruyucu Fizyoterapinin Önemi}

\author{
Kadirhan Özdemir1, İlke Keser1, İlker Șen2, Mustafa Özgür Tan2 \\ 1 Gazi University Faculty of Health Sciences, Department of Physiotherapy and Rehabilitation, Ankara, Turkey \\ 2 Gazi University Faculty of Medicine, Department of Urology, Ankara, Turkey
}

\section{What's known on the subject? and What does the study add?}

Only 5.8\% of prostate cancer ( $\mathrm{PCa}$ ) patients invited to this study participated in preventive physiotherapy applications. The reason why the participation rate is very low, PCa patients may have not enough knowledge and awereness about physiotherapy. It is expected that awareness of patients will increase as long as physiotherapy and rehabilitation area improves in PCa.

\section{ABSTRACT}

Objective

Prostate cancer (PCa) is observed in men aged 50 years and older. The incidence increases in parallel to aging. Survival rate for PCa increases with effective screening programs and therapies. Elongated life expectancy may lead to a decrease in quality of life, muscle strength and physical activity level; an increase in fatigue and sleep problems. To preclude the occurrence of these symptoms, the preventive physiotherapy approaches may be used in PCa patients. The aim of this study was to investigate the attitude of patients with $\mathrm{PCa}$ towards preventative physiotherapy approaches.

\section{Materials and Methods}

Patients who were diagnosed with PCa in Gazi University Faculty of Medicine, Department of Urology were invited to participate in the preventive physiotherapy services provided in Gazi University, Faculty of Health Sciences, Department of Physiotherapy and Rehabilitation, Oncologic Rehabilitation Unit.

\section{Results}

Three hundred forty-four patients were invited, only $20(5.8 \%)$ patients participated in the study. Twenty $(5.8 \%)$ patients did not attend the appointment despite agreeing to participate in the study. Other 304 $(88.4 \%)$ patients did not join the study for several reasons.

\section{Conclusion}

The reason for low participation rate may be inadequate information of $\mathrm{PCa}$ patients about preventive physiotherapy. The results of this study highlight the need for making preventive physiotherapy applications recognizable for $\mathrm{PCa}$ patients.

\section{Keywords}

Physiotherapy and rehabilitation, awareness, cancer rehabilitation

\section{ÖZ}

Amaç

Prostat kanseri (PKa) 50 yaş ve üzeri erkeklerde görülmektedir. Görülme sıklığı artan yaş ile doğru orantılı olarak artmaktadır. Uygulanan tarama programları ve tedaviler sayesinde PKa hastalarının sağkalım oranları yükselmektedir. Artan yaşam beklentileri bu hasta grubunda yaşam kalitesi, kas kuvveti ve fiziksel aktivite düzeyinde azalmaya; yorgunluk ve uyku problemlerinde artmaya neden olabilir. Bu semptomların oluşmasını önlemek amacıyla PKa hastalarında koruyucu fizyoterapi yöntemleri uygulanabilir. Bu çalışmanın amacı, PKa tanılı hastaların koruyucu fizyoterapiye olan yaklaşımlarını incelemektir.

\section{Gereç ve Yöntem}

Gazi Üniversitesi Tıp Fakültesi, Üroloji Anabilim Dalı'nda PKa tanısı alan hastalar, Sağlık Bilimleri Fakültesi Fizyoterapi ve Rehabilitasyon Anabilim Dalı Onkolojik Rehabilitasyon Ünitesi'nde uygulanan koruyucu fizyoterapi hizmetlerine katılmaları önerilerek çalışmaya davet edildi.

\section{Bulgular}

Davet edilen 344 kişiden sadece 20'si $(\% 5,8)$ çalışmaya katıldı. Yirmi $(\% 5,8)$ hasta çalışmaya katılmayı kabul etmesine rağmen randevusuna gelmedi. Geriye kalan $304(\% 88,4)$ hasta çeşitli sebeplerden dolayı çalışmaya katılmadı.

\section{Sonuç}

Katılım oranının bu kadar düşük olmasının sebebi PKa hastalarının koruyucu fizyoterapi hakkında yeterli bilgiye sahip olmamaları olabilir. Bu çalışmanın sonuçları, PKa hastalarında koruyucu fizyoterapi uygulamalarının daha tanınır hale getirilmesinin gerekliliğini vurgulamıştır.

Anahtar Kelimeler

Fizyoterapi ve rehabilitasyon, farkındalık, kanser rehabilitasyonu

\section{Correspondence}

Kadirhan Özdemir, MSc, PT, Gazi University Faculty of Health Sciences, Department of Physiotherapy and Rehabilitation, Ankara, Turkey

Phone: +90 2323244543 E-mail: kadirhanozdemir@gmail.com Received: 20.04.2016 Accepted: 29.07.2016 


\section{Introduction}

Usually seen in men over age 50, prostate cancer (PCa) is the second most commonly diagnosed type of invasive cancer in Turkey, after lung cancer (1). It metastasizes to external iliac, obturatory and internal iliac lymph nodes (2), lumbosacral vertebrae, and the pelvic bone (3). According to the Public Health Institute of Turkey Health Statistics Yearbook 2016, crude age-adjusted rate for PCa is 33.7 per 100.000. This value increases with age; and may be as much as 410.7 per 100.000 in men aged 85 and older (1). Screening programs have reduced PCa mortality and increased survival rates in developed countries (4). Five-year survival rates have reached as high as 99\% because of early treatment. However, because of prolonged survival, patients now have to deal with the effects of cancer and cancer treatment (5).

PCa can be clinically classified into the following groups: localized, locally advanced, and metastatic (6). In the literature, available treatments for $\mathrm{PCa}$ according to stage include active surveillance, radical prostatectomy, external-beam radiation therapy, androgen deprivation therapy (ADT), brachytherapy, cryotherapy, high-intensity focused ultrasound, and chemotherapy (7). In recent studies, radiofrequency (8), immunotherapy (9) and targeted therapies (10) are also mentioned.

Problems that arise in patients with PCa include erectile dysfunctionand urinary incontinence-associated decrease in quality of life due to radical prostatectomy and radiotherapy (11). In addition, sarcopenia (12), fatigue (13), sleep problems (14), and decreased muscle mass and strength (15) due to chemotherapy and androgen deprivation therapy are also seen. Today, physiotherapy and rehabilitation methods increasing the quality of life become more important to reduce the negative effects of treatment complications (16). Moreover, because of the age at diagnosis, elderly patients with PCa may also have geriatric problems (balance and gait disorders, muscle weakness, orthostatic hypotension, increased risk for fractures, and decrease in cardiopulmonary function) along with cancer-related problems $(17,18)$.

Preventive rehabilitation approaches reduce potential disabilities and involves patient education. Additionally, they include promotion and protection of health, treatment, and rehabilitation (19). Moreover, they promote physical and general health condition of the patient. Preventive approaches implemented before the potential disability develops are expected to reduce the severity or duration of the disability. Therapeutic exercises before early diagnosis and treatment are usually for preventive purposes (20). However, in PCa patients, it has been reported that activities focused on the prevention of potential modifiable risk factors (i.e. physical inactivity) are insufficient (21). These preventive approaches seek to balance the side effects of surgery, chemotherapy, or radiotherapy by increasing the cardiopulmonary capacity, strength and functionality (20). The aim of this study was to examine PCa patients' attitude towards preventive physiotherapy and its applications. With this aspect, this is the first study on preventive physiotherapy in patients with PCa.

\section{Materials and Methods}

Patients diagnosed with PCa in the urology outpatient clinic at
Gazi University Faculty of Medicine were recommended to take part in preventive physiotherapy services held at Faculty of Health Sciences, Department of Physiotherapy and Rehabilitation, Oncologic Rehabilitation Unit between March 2014 and January 2015. The patients were invited to take part in the study either face-to-face at the outpatient clinic, or on the phone after being informed. The patients were informed by the physiotherapist and invited to take part in the preventive physiotherapy sessions on a volunteer basis.

The steps of the oncology rehabilitation follow the changes in the patient's functional status independent from cancer stage or treatment, and focus on loss of function. The patients were classified into 4 categories of treatment according to classification made by Dr. Dietz $(22,23)$ :

1. Preventive,

2. Restorative,

3. Supportive,

4. Palliative rehabilitation.

Patients without mobility and balance problems due to cancer or cancer treatment and could independently mobilize were included in the study to receive recommendations on preventive physiotherapy. Patients requiring active oncology rehabilitation and those with metastases were excluded from the study.

As a part of the preventive physiotherapy interventions, the patients were told that they would receive information on detailed physiotherapy evaluations for determining their current status, and physiotherapeutic approaches towards possible future problems. A brochure titled "Prostate Cancer and Exercise" was prepared, and the patients were informed that they would receive it. This brochure included information about the goals of physiotherapy and rehabilitation in $\mathrm{PCa}$, the need for/benefits of exercise in $\mathrm{PCa}$, how and why patients should start doing exercises, and which type of exercises they should be doing. Also, patients with urinary incontinence were informed that they would be taught Kegel exercises as a home treatment program.

\section{Statistical Analysis}

Number of patients and the frequency of their symptoms were presented as percentages using SPSS version 15.0.

\section{Results}

Records of 383 patients diagnosed with PCa in the urology outpatient clinic were evaluated. It was found that 33 patients had metastases, and 6 had passed away. A total of 344 patients were invited to participate in the study, but 304 (88.4\%) refused participation for various reasons. The most cited reason was never having heard of the term "physiotherapy" and not knowing which interventions it includes. One hundred-eighty-eight (54.7\%) patients refused to take part in the study saying that it would not solve their current problem. The leading problem was erectile dysfunction. One hundred-six (30.8\%) of patients did not want to participate in to the study for not living in the same city and difficulties in transportation. Ten (2.9\%) patients mentioned not having time for the study. Twenty (5.8\%) patients accepted the invitation but did not come to the appointment. The 


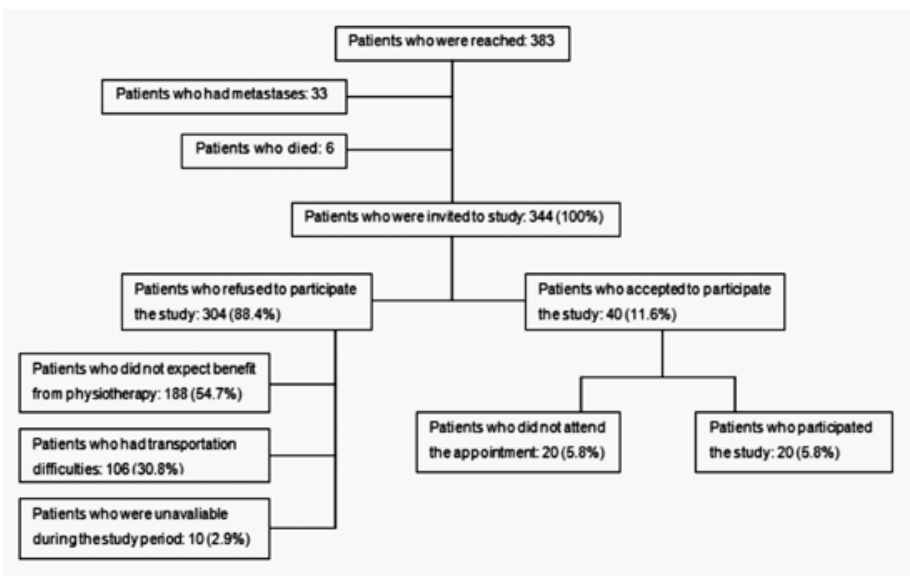

Figure 1. Number of invited patients and their percentage

study was completed with 20 (5.8\%) patients (Figure 1).

The mean age of the subjects was $65.5 \pm 6.7$ years, and the mean body mass index was $29.93 \pm 3.76 \mathrm{~kg} / \mathrm{m}^{2}$. The most reported symptoms were erectile dysfunction (85\%, $n=18)$, urinary incontinence $(35 \%$, $n=7)$, fatigue $(20 \%, n=4)$, frequent urination $(15 \%, n=3)$, incomplete bladder emptying $(10 \%, n=2)$, and fecal incontinence $(5 \%, n=1)$.

\section{Discussion}

At the end of this study, we observed that $94.2 \%$ of the PCa patients invited to the study did not take part in the physiotherapy interventions. The fact that PCa patients heard the term "physiotherapy" for the first time when they were informed about the study and they did not have enough knowledge about the role and benefits of physiotherapy in cancer rehabilitation may explain their hesitation about taking part in the study. This has significantly reduced the rate of participation.

There have been various studies evaluating PCa awareness and knowledge on prevention of $\mathrm{PCa}$ in the current literature. One of two studies, both run on black people, has reported that participants' awareness of PCa was poor and the other one has reported moderate level of awareness $(21,24)$. Apart from lack of education on $\mathrm{PCa}$, it may be postulated that knowledge and information about preventive approaches are also insufficient. The fact that activities for avoiding potential modifiable risk factors (i.e. physical inactivity) are not known well enough (21) emphasizes the importance of preventive physiotherapy in PCa. Studies on physiotherapy awareness performed in Turkey have focused on students instead of patient groups (25). Therefore, awareness of patient groups about physiotherapy practices in general has not been illuminated.

Low study participation, despite the patients received information about the role of and need for physiotherapy in $\mathrm{PCa}$, may be due to different expectations of patients. It is known that the most important information that PCa patients want to have include treatment options, disease stage, risks and benefits of the treatment, and side effects of treatments $(26,27,28)$. This may be the same for patients we reached out to for this study. This study consisted of effective methods to prevent the most important function-related problems that the PCa patient group may have, however, the patients invited to the study preferred to focus on problems they had at that moment. Particularly, erectile dysfunction which has a direct effect on quality of life is a common side effect of usual PCa treatments like radical prostatectomy, external radiotherapy, and ADT (29). 54.7\% of the 344 patients who were invited to the study mentioned that they did not want to participate because it would not help with erectile dysfunction. Although there are applications for the treatment of erectile dysfunction in the field of physiotherapy and rehabilitation (30), the fact that we focused on possible future problems instead of current ones in the context of preventive physiotherapy may have affected participation rate. Elderly patients, who were considered geriatric patients ignored the benefits of preventive physiotherapy and rehabilitation interventions by not accepting the invitation to participate in this study.

The results of a systematic review and meta-analysis support the hypotheses that exercise approaches improve PCa-related quality of life and fatigue, submaximal physical fitness, and lower body strength (31). Another review involving observational epidemiological studies has shown associations between physical activity and $\mathrm{PCa}$ risk. Moreover, it has been reported that there was an association between advanced or aggressive disease and risk of death from PCa (32). A prospective study on the other hand has shown that the risk of PCa was increased in physically inactive black men (33). Considering these causes, it becomes obvious that PCa patients should be informed about positive effects of physical activity and exercise during the course of PCa.

Globally, the literature in the field of physiotherapy and rehabilitation in PCa dates back to 1987 (34). In Turkey, however, the first study in this field was made as a master thesis in 2015 (35)." The fact that PCa patients in Turkey are informed late about interventions by physiotherapists may have caused lower knowledgeability about this subject in this patient group. As the field of physiotherapy and rehabilitation in $\mathrm{PCa}$ develops, we expect patient awareness to increase too.

\section{Study Limitations}

The reasons for low patient participation and patient knowledgeability about physiotherapy may be evaluated in detail with questions. However, as the study was planned, this low level of participation was not foreseen as we did not know how low patient awareness on physiotherapy was, and thus did not use a detailed measuring tool including these questions.

\section{Conclusion}

At the end of this study, the low knowledgeability of PCa patients about physiotherapy and its scope may have reduced the participation in preventive physiotherapy interventions. Additionally, we observed that PCa patients were more focused on the current situation and their current symptoms and, did not regard possible future problems as important enough. This study has shown that PCa patients should be informed more about preventive physiotherapy interventions.

\section{Ethics}

Ethics Committee Approval: This study was carried out according to Gazi University Ethics Committee's report number 77082166604.01.02-6837, date March 11th, 2014, Informed Consent: Participants filled in an informed consent form. 
Peer-review: Internal peer-reviewed.

\section{Authorship Contributions}

Concept: Kadirhan Özdemir, İlke Keser, Design: Kadirhan Özdemir, İlke Keser, Data Collection or Processing: Kadirhan Özdemir, IIlke Keser, IIlker Şen, Mustafa Özgür Tan, Analysis or Interpretation: Kadirhan Özdemir, Literature Research: Kadirhan Özdemir, Writing: Kadirhan Özdemir, ilke Keser.

Conflict of Interest: No conflict of interest was declared by the authors.

Financial Disclosure: The authors declared that this study has received no financial support.

\section{References}

1. Şencan İ, İnce GN. Türkiye Cumhuriyeti Sağlık Bakanlığı Türkiye Halk Sağlığı Kurumu: Sağlık İstatistikleri Yıllığı, Sağlık Bakanlığı. Ankara, 2016, pp. 19-21.

2. Mattei A, Fuechsel FG, Bhatta Dhar N, Warncke SH, Thalmann GN, Krause $T$, Studer UE. The template of the primary lymphatic landing sites of the prostate should be revisited: results of a multimodality mapping study. Eur Urol 2008;53:118-125.

3. Balbay D. Prostat. Ankara, Güneş Tıp Kitabevleri, 2008, pp. 199-208.

4. Helgesen $F$, Holmberg $L$, Johansson JE, Bergström R, Adami HO. Trends in prostate cancer survival in Sweden, 1960 through 1988: evidence of increasing diagnosis of nonlethal tumors. J Natl Cancer Inst 1996;88:1216-1221

5. Badger TA, Segrin C, Figueredo AJ, Harrington J, Sheppard K, Passalacqua $\mathrm{S}$, Pasvogel A, Bishop M. Psychosocial interventions to improve quality of life in prostate cancer survivors and their intimate or family partners. Qual Life Res 2011;20:833-844.

6. Kozacıoğlu Z, Günlüsoy B. Lokal ileri evre prostat kanserinde güncel tedavi yaklaşımları: ürolog yaklaşımı. Bulletin of Urooncology 2012;2:124-128.

7. Heidenreich $A$, Bastian PJ, Bellmunt J, Bolla M, Joniau S, van der Kwast $T$, Mason M, Matveev V, Wiegel T, Zattoni F, Mottet N; European Association of Urology. EAU guidelines on prostate cancer. part 1: screening, diagnosis, and local treatment with curative intent-update 2013. Eur Urol 2014;65:124-137.

8. Shariat SF, Raptidis G, Masatoschi M, Bergamaschi F, Slawin KM. Pilot study of radiofrequency interstitial tumor ablation (RITA) for the treatment of radio-recurrent prostate cancer. Prostate 2005;65:260-267.

9. Lekili M. Prostat kanserinde immunoterapi. Bulletin of Urooncology 2011;10:82-84

10. Demirkazık A, Özal G. Prostat kanserinde hedefe yönelik tedavinin yeri. Bulletin of Urooncology 2010;9:64-68.

11. Penson DF, Litwin MS, Aaronson NK. Health related quality of life in men with prostate cancer. J Urol 2003;169:1653-1661.

12. Smith MR, Saad F, Egerdie B, Sieber PR, Tammela TL, Ke C, Leder BZ, Goessl C. Sarcopenia during androgen-deprivation therapy for prostate cancer. J Clin Oncol 2012;30:3271-3276.

13. Stone PC, Minton O. Cancer-related fatigue. Eur J Cancer 2008;44:10971104.

14. Garrett K, Dhruva A, Koetters T, West C, Paul SM, Dunn LB, Aouizerat BE, Cooper BA, Dodd M, Lee K, Wara W, Swift P, Miaskowski C. Differences in sleep disturbance and fatigue between patients with breast and prostate cancer at the initiation of radiation therapy. J Pain Symptom Manage 2011;42:239-250.
15. Potosky AL, Reeve BB, Clegg LX, Hoffman RM, Stephenson RA, Albertsen $P C$, Gilliland FD, Stanford JL. Quality of life following localized prostate cancer treated initially with androgen deprivation therapy or no therapy. J Natl Cancer Inst 2002;94:430-437.

16. Bennett CJ, Grant MJ. Specialisation in physiotherapy: a mark of maturity. Aust J Physiother 2004;50:3-5.

17. Rubenstein $L Z$, Josephson KR. Falls and their prevention in elderly people: what does the evidence show? Med Clin North Am 2006;90:807-824.

18. Friedenreich CM, Wang Q, Neilson HK, Kopciuk KA, McGregor SE, Courneya KS. Physical Activity and Survival After Prostate Cancer. Eur Urol 2016.

19. http://www.wcpt.org/sites/wcpt.org/files/files/PS_Description_PT_ Sept2011_FORMATTED_edit2013.pdf. Erişim tarihi: 25/07/2016.

20. Stubblefield MD. Cancer rehabilitation. Semin Oncol 2011;38:386-393.

21. Morrison BF, Aiken WD, Mayhew R, Gordon $Y$, Odedina FT. Prostate cancer knowledge, prevention, and screening behaviors in jamaican men. J Cancer Educ 2016.

22. Okamura $\mathrm{H}$. Importance of rehabilitation in cancer treatment and palliative medicine. Jpn J Clin Oncol 2011;41:733-738.

23. Dietz JH Jr. Rehabilitation of the cancer patient. Med Clin North Am 1969;53:607-624.

24. Nakandi $H$, Kirabo $M$, Semugabo $C$, Kittengo $A$, Kitayimbwa $P$, Kalungi $S$, Maena J. Knowledge, attitudes and practices of Ugandan men regarding prostate cancer. Afr J Urol 2013;19:165-170.

25. Özdinçler A, Tarakçi E, Aslan Y. Fizyoterapi ve Rehabilitasyon Bölümü Öğrencilerinin Mesleki Farkındalık Düzeylerinin İncelenmesi. Sağlık Bilimleri ve Meslekleri Dergisi 2015;2:217-222.

26. Davison BJ, Degner LF, Morgan TR. Information and decisionmaking preferences of men with prostate cancer. Oncol Nurs Forum 1995;22:1401-1408.

27. Davison BJ, Gleave ME, Goldenberg SL, Degner LF, Hoffart D, Berkowitz $J$. Assessing information and decision preferences of men with prostate cancer and their partners. Cancer Nursing 2002;25:42-49.

28. Davison BJ, Goldenberg SL, Wiens KP, Gleave ME. Comparing a generic and individualized information decision support intervention for men newly diagnosed with localized prostate cancer. Cancer Nurs 2007;30:715.

29. Jani $A B$, Hellman S. Early prostate cancer: clinical decision-making. Lancet 2003;361:1045-1053.

30. Bernardo-Filho $M$, Barbosa Júnior $M L$, da Cunha Sá-Caputo $D$, de Aguiar Ede 0, de Lima RP, Santos-Filho SD, de Paoli S, Presta GA, de Oliveira Bravo Monteiro $M$, Tavares $A$. The relevance of the procedures related to the physiotherapy in the interventions in patients with prostate cancer: short review with practice approach. Int J Biomed Sci 2014;10:73-84.

31. Bourke L, Smith D, Steed L, Hooper R, Carter A, Catto J, Albertsen PC, Tombal B, Payne HA, Rosario DJ. Exercise for men with prostate cancer: a systematic review and meta-analysis. Eur Urol 2016;69:693-703.

32. Wekesa $A$, Harrison M, Watson RW. Physical activity and its mechanistic effects on prostate cancer. Prostate Cancer and Prostatic Dis 2015;18:197207.

33. Clarke G, Whittemore AS. Prostate cancer risk in relation to anthropometry and physical activity: the National Health and Nutrition Examination Survey I Epidemiological Follow-Up Study. Cancer Epidemiol Biomarkers Prev 2000;9:875-881.

34. Ballanger $R$, Ballanger P. Treatment of cancer of the prostate by use of physiotherapy: long term results. Prog Clin Biol Res 1987;243:213-214.

35. Özdemir K. Prostat kanseri tanılı hastalarda uyku kalitesi, yorgunluk, yaşam kalitesi, fiziksel aktivite, alt ekstremite fiziksel fonksiyonları, denge ve mobilite arasındaki ilişkinin incelenmesi Yüksek Lisans. Gazi Üniversitesi, 2015. 